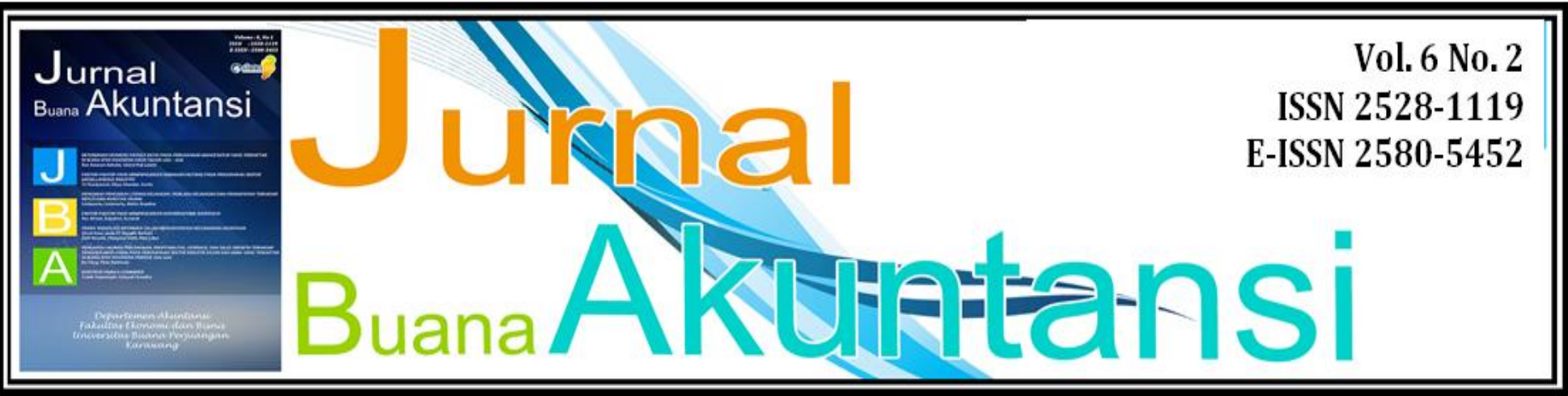

\title{
SIFAT MACHIAVELLIAN DAN LOCUS OF CONTROL : STUDI EKSPERIMEN KEPUTUSAN ETIS KONSULTAN PAJAK
}

\author{
1Yenny Muliawaty, 2Dian Purnama Sari \\ 1,2 Pascasarjana Universitas Katolik Widya Mandala Surabaya \\ ${ }^{1}$ yenny.muliawaty@gmail.com
}

\begin{abstract}
Abstrak Penelitian ini menguraikan mengenai fenomena yang melibatkan konsultan pajak dalam beberapa kasus pelanggaran etika, salah satu kasus pada tahun 2020 yang dimana merugikan negara sebesar Rp 19,966 miliar lebih hal yang dilakukan oleh pihak konsultan pajak ialah membuatkan faktur pajak fiktif. Tujuan dari penelitian ini adalah untuk menganalisis dan mengetahui perbedaan konsultan pajak yang memiliki sifat Machiavellian tinggi atau rendah dan kecenderungan internal atau eksternal locus of control terhadap pengambilan keputusan etis. Metode yang digunakan dalam penelitian ini yaitu eksperimen dengan desain faktorial $2 \times 2$ between subject. Partisipan yang berpartisipasi dalam penelitian eksperimen ini adalah konsultan pajak yang terdaftar di Ikatan Konsultan Pajak Indonesia (IKPI) cabang Surabaya. Data yang diperoleh dari eksperimen dianalisis dengan uji One Way ANOVA. Hasil ekpserimen menunjukkan bahwa semakin tinggi sifat Machiavellian yang dimiliki konsultan pajak maka keputusan yang akan diambil semakin tidak etis. Sebaliknya, semakin rendah sifat Machiavellian yang dimiliki konsultan pajak maka keputusan yang akan diambil semakin etis. Seseorang dengan locus of control tinggi yang memiliki kecenderungan internal locus of control akan lebih cenderung mengambil keputusan etis dibandingkan seseorang dengan locus of control rendah yang memiliki kecenderungan eksternal locus of control.
\end{abstract}

Kata kunci: Sifat Machiavellian, Locus of Control, Keputusan Etis

\section{Pendahuluan}

Peraturan perpajakan di Indonesia bisa terbilang kompleks karena penafsiran akan peraturan sendiri bisa memiliki pemahaman yang berbeda antara masing-masing wajib pajak. Wawasan dan pengertian mayoritas wajib pajak yang sangat minim tentang peraturan perpajakan membuat mereka menggunakan jasa konsultan pajak untuk 


\section{Buana Akuntansi}

YENNY MULIAWATY

Vol. 6 No. 2

ISSN 2528-1119

E-ISSN 2580-5452

membantu mengatasi permasalahan perpajakan mereka. Blanthorne, Burton dan Fisher (2013) berpendapat bahwa konsultan pajak rentan dihadapkan pada dilema etis dimana tekanan klien menciptakan insentif untuk mengeksploitasi pelaporan untuk keuntungan pribadi sedangkan di saat yang sama, konsultan pajak memiliki kewajiban profesional untuk menjaga integritas sistem perpajakan.

Konsultan pajak harus membuat suatu keputusan yang menyebabkan dilema etis terjadi karena keputusan tersebut dapat berlawanan dengan etika profesionalitasnya namun menghasilkan imbalan ekonomis yang cukup material dimana keputusan yang akan dibuat tersebut diharapkan tidak bertentangan dengan nilai-nilai etika. Hal ini membuat konsultan pajak akan melakukan berbagai cara dengan memanfaatkan celah peraturan perpajakan meskipun hal tersebut melanggar etika profesi mereka. Pada bulan Juli tahun 2020, profesi konsultan pajak dihebohkan dengan tertangkapnya Maringan P. Siagian seorang konsultan pajak yang menyebabkan kerugian Negara sebesar Rp 19,966 miliar lebih. Maringan selaku konsultan pajaknya diketahui membantu klien nya untuk menerbitkan faktur pajak fiktif.

Menurut teori planned behavior (TPB), pada saat individu sedang memperhitungkan perilaku mereka dan keterkaitan dari perilakunya dalam mengambil keputusan maka mereka akan berpikir secara rasional. Doyle, Hughes dan Summers (2013) menjelaskan bahwa seseorang yang dalam kondisi mempertimbangkan masalah dalam konteks perpajakan dapat menimbulkan pemikiran untuk berperilaku tidak etis. Immanuel Kant berpendapat bahwa manusia memiliki penalaran moral yang rasional sehingga mampu mengambil keputusan secara etis bukan didasarkan pada kepentingan diri sendiri dan keuntungan diri (Jiang dan Bowen, 2011). Jones (1991) berpendapat bahwa teori penalaran moral Kohlberg menjadi operatif saat seseorang berada dalam dilema etis dimana faktor-faktor yang mempengaruhi penalaran moral dapat berasal dari individu dan situasional. Profesi konsultan pajak mempunyai kode etik profesi yang mengontrol semua etika profesi yang wajib dipatuhi oleh para profesional. IKPI merupakan asosiasi konsultan pajak pertama yang diakui oleh negara sejak berdiri tahun 1965, Menurut kode etik profesi yang tertuang dalam kode etik IKPI dijelaskan bahwa apabila seorang konsultan pajak terlibat dalam permasalahan hukum maka ijin konsultannya akan dibekukan bahkan bisa jadi malah dicabut.

Machiavellian merupakan sifat individu seseorang dimana seseorang memiliki kecenderungan secara agresif untuk memengaruhi serta mengendalikan lingkungan di sekitarnya untuk memenuhi kepentingan pribadinya. Suatu profesi mengharuskan seseorang untuk bersikap profesional dengan memiliki tanggung jawab etis sehingga sifat Machiavellian akan bertentangan dengan kode etik yang telah ditetapkan. Berdasarkan studi yang dilakukan oleh Silitonga dan Hidayat (2019), semakin tinggi sifat Machiavellian konsultan pajak dapat menyebabkan seseorang cenderung membuat keputusan yang tidak etis dan begitu juga sebaliknya. Penelitian yang dilakukan oleh Tofiq dan Mulyani (2018) mengenai sifat Machiavellian memiliki hasil yang bertolak 


\section{Buana Akuntansi}

YENNY MULIAWATY

Vol. 6 No. 2

ISSN 2528-1119

E-ISSN 2580-5452

belakang dimana sifat Machiavellian kurang berpengaruh terhadap pengambilan keputusan etis konsultan pajak karena sifat tersebut dianggap bukan hal yang penting bagi konsultan pajak.

Selain sifat Machiavellian, menurut Uli, Tanjung dan Paulus, 2016 dikatakan bahwa ketika seseorang sedang berada di kondisi konflik, maka perilaku seorang auditor akan dipengaruhi oleh karakter locus of control-nya. Yovita dan Rahmawaty (2016) menjelaskan individu yang memiliki locus of control yang baik akan membuat seseorang bekerja dengan baik dan berperilaku etis. Studi yang dilakukan oleh Anjelina (2019) menemukan hasil yang bertolak belakang dimana locus of control diketahui bahwa tidak mempunyai pengaruh atas sensitivitas etis mahasiswa akuntansi Universitas Soegijapranata Semarang.

Dalam kebaruan penelitian ini, obyek penelitian akan menggunakan konsultan pajak yang terdaftar di IKPI Cabang Surabaya. Metode penelitian yang akan digunakan ialah metode penelitian eksperimen dengan desain faktorial $2 \times 2$, diharapkan hasil dari penelitian dapat menjadi masukan dan pertimbangan bagi para konsultan pajak dalam melaksanakan pekerjaannya mengingat pengaruh sifat Machiavellian dan locus of control terhadap pengambilan keputusan etis konsultan pajak.

\section{Tinjauan Pustaka}

\subsection{Landasan Teori}

\subsubsection{Teori Planned Behavior}

Teori planned behavior yaitu teori yang dikemukakan oleh Ajzen pada tahun 1991 mengenai perilaku manusia. Menurut Mahyarni (2013), theory of planned behavior adalah teori yang memiliki fungsi untuk memperkirakan tindakan seseorang saat seseorang tidak memiliki kontrol atas perilaku nya secara penuh. Teori ini adalah perluasan dari theory of reasoned action yang dicetuskan Ajzen di tahun 1975. Ajzen menjelaskan bahwa elemen penting da

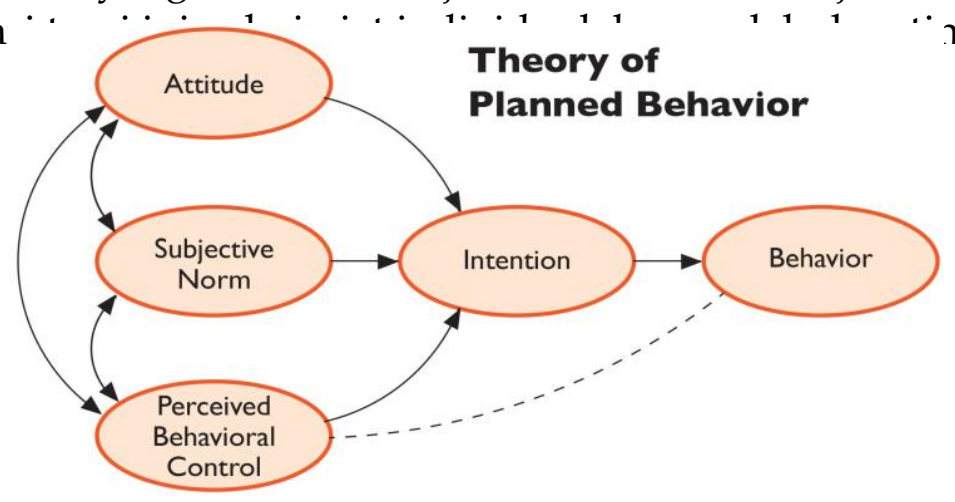

Sumber: Ajzen (1991:182)

Teori planned behavior memiliki tiga konstruk antara lain sikap, norma subjektif dan persepsi kontrol perilaku (Mahyarni 2013). Pertama, sikap atas tindakan seseorang didasari keyakinan yang didapat akibat efek tindakan tersebut apakah memberikan 


\section{Buana Akuntansi}

YENNY MULIAWATY

Vol. 6 No. 2

ISSN 2528-1119

E-ISSN 2580-5452

kerugian atau keuntungan baginya. Keyakinan yang dimiliki seseorang akan memperkuat perilaku yang akan dihasilkan. Kedua, norma subjektif dimana keyakinan seseorang akan harapan atau pandangan sekitarnya terhadap keputusan akan perilaku yang diambilnya. Ketiga, persepsi kontrol perilaku dimana persepsi ini didasari keyakinan seseorang tentang adanya sumber daya serta peluang yang mendukung atau menghambat terwujudnya tindakan tersebut. Kontrol seseorang terhadap perilakunya dapat disebabkan oleh faktor internal (seperti kemampuan, kemauan, informasi) maupun eksternal (berasal dari lingkungan sekitar).

Menurut teori planned behavior, pada saat individu sedang memperhitungkan perilaku mereka dan keterkaitan dari perilakunya dalam mengambil keputusan maka mereka akan berpikir secara rasional. Individu akan melakukan penalaran moral agar dapat membuat keputusan yang rasional dimana individu tersebut sadar akan dampak dan konsekuensi dari keputusan yang diambil sehingga memberikan hasil yang maksimal (Mahyarni, 2013). TPB mengemukakan bahwa sikap akan memberi dampak pada tindakan melewati mekanisme pengambilan keputusan yang cermat serta direncanakan, kemudian seseorang akan melakukan tindakan tertentu saat tindakannya mendapat respon yang baik. Seseorang yakin bahwa orang lain juga mendukung tindakannya serta yakin kalau dia mampu melaksanakannya (Damayanti Sutrisno, subkteri dan Baridwan, 2015).

\subsubsection{Teori Penalaran Moral}

Menurut Lubis (2017: 523), teori psikologi penalaran moral (moral reasoning) biasanya digunakan sebagai landasan mayoritas studi akuntansi untuk meneliti perilaku etis akuntan. Kohlberg (Lubis, 2017: 523) menjelaskan penalaran moral adalah penilaian terhadap nilai, penilaian sosial, dan juga penilaian atas tanggung jawab yang menuntut seseorang ketika berperilaku. Menurut teori yang dikemukakan oleh Kohlberg (Santrock, 2007: 119), ketika seseorang berada dalam dilema moral, seseorang akan memiliki tiga tingkatan penalaran moral dimana masing-masing tingkatan mempunyai dua fase.

Teori psikologi mengenai penalaran moral menjelaskan bahwa proses menguraikan kondisi permasalahan yang dihadapi individu sebelum membuat keputusan etis. Rest (Lubis, 2017: 524) mengemukakan tahapan Kohlberg merupakan komponen yang integral dari model kognitif komprehensif pengambilan keputusan etis. Menurut Rest (Lubis, 2017: 524) salah satu komponen dalam menentukan perilaku etis, yaitu keputusan etis dimana keputusan tentang kebenaran perilaku secara moral.

\subsubsection{Pengambilan Keputusan Etis}

Etika berawal dari bahasa Yunani dari kata ethos (bentuk tunggal) yang mempunyai pengertian kebiasaan, adat, watak, sikap dan cara berpikir. Rahardjo (2018: 3) berpendapat bahwa pengertian etika secara etimologis yaitu suatu ilmu yang mempelajari mengenai adat atau kebiasaan yang berhubungan dengan perilaku baik 


\section{Buana Akuntansi}

YENNY MULIAWATY

Vol. 6 No. 2

ISSN 2528-1119

E-ISSN 2580-5452

dan yang buruk. Etika memiliki pengertian dimana perilaku yang terbentuk dari moral masyarakat saat menerapkan aturan sehingga menghargai adat istiadat yang berlaku di sekitarnya (Fahmi, 2017: 2). Moral merupakan perilaku maupun kegiatan yang membedakan baik ataupun buruk yang didasarkan pada aturan yang berlaku di sekitar.

Keputusan etis yaitu suatu keputusan yang diambil seseorang berdasarkan etika yang berlaku tanpa melanggar aturan-aturan serta norma yang ada. Pengambilan keputusan merupakan kondisi dimana seseorang dihadapkan pada pemilihan tindakan dari dua atau lebih alternatif yang ada. Pengambilan keputusan etis merupakan suatu keputusan yang melalui proses pertimbangan didasarkan pada etika yang tidak melanggar norma hukum sehingga mampu dipertanggungjawabkan secara moral (Pitaloka dan Ardini, 2017). Menurut Dewi dan Dwiyanti (2018), pengambilan keputusan etis dapat dibedakan berdasarkan jenis pengambilan keputusan diambil yang didasarkan pada prinsip-prinsip etis yaitu latar belakang yang digunakan dalam menghasilkan suatu keputusan serta penalaran moral pengambil keputusan.

Menurut Fahmi (2017: 2), penalaran moral yang dimiliki seseorang dapat mempengaruhi dalam mengambil suatu keputusan. Jones (1991) berpendapat bahwa teori penalaran moral Kohlberg menjadi operatif saat seseorang berada dalam dilema etis dimana faktor-faktor yang mempengaruhi penalaran moral dapat berasal dari individu dan situasional. Selain itu, adanya konflik kepentingan dapat ikut menentukan pertimbangan baik dan buruk (Rahardjo, 2018: 463). TPB mengemukakan bahwa sikap akan memberi dampak pada tindakan melewati mekanisme pengambilan keputusan yang cermat serta direncanakan, kemudian seseorang akan melakukan tindakan tertentu saat tindakannya mendapat respon yang baik. Seseorang yakin bahwa orang lain juga mendukung tindakannya serta yakin kalau dia mampu melaksanakannya (Damayanti dkk, 2015).

\subsubsection{Sifat Machiavellian}

Machiavellianism merupakan karakter kepribadian menurut Niccolo Machiavelli yang menulis mengenai bagaimana caranya memperoleh dan menggunakan kekuatannya (Lubis, 2017: 162). Menurut Jones dan Paulhus (2009: 95), Machiavellian memiliki pengertian sebagai suatu sifat yang dimiliki seseorang dimana perilaku manipulatif merupakan hal yang wajar dilakukan seseorang demi mencapai tujuan pribadinya. Seorang yang melakukan manipulator akan memperoleh lebih banyak reward dibandingkan saat tidak melakukan manipulasi. Seseorang yang mempunyai sifat Machiavellian mempunyai kecenderungan memanipulasi orang lain untuk mencapai tujuan pribadinya.

Purnamasari dan Chrismastuti (2006) mengatakan individu yang mempunyai sifat Machiavellian yang tinggi lebih suka melakukan manipulatif dan juga melakukan penipuan serta mereka akan melakukan segala cara demi keuntungan pribadinya. 


\section{Buana Akuntansi}

YENNY MULIAWATY

Vol. 6 No. 2

ISSN 2528-1119

E-ISSN 2580-5452

Mereka kurang memiliki moral yang baik sehingga dapat menyebabkan perilaku tidak etis karena mereka tidak akan segan untuk melanggar aturan dalam kode etik profesi mereka demi mencapai tujuan pribadinya (Saputri dan Wirama, 2015). Nikara dan Mimba (2019) menjelaskan bahwa seseorang yang Machiavellian cenderung tinggi lebih mengutamakan hasil daripada proses sehingga mereka memiliki sifat lebih agresif. Mereka lebih berfokus pada hasil yang mereka capai harus memuaskan sehingga terkadang mereka akan melakukan apapun meskipun tindakan yang dilakukan termasuk tindakan yang tidak etis dan kurang memiliki tanggung jawab sosial.

Selain itu, Suzila (2018) mengungkapkan bahwa individu dengan sifat Machiavellian yang tinggi condong membuat keputusan berdasarkan keinginan pribadi mereka menggunakan berbagai cara seperti manipulasi, berbohong bahkan melanggar etika ketika dihadapkan pada masalah yang berkaitan dengan moral. Individu dengan sifat Machiavellian tinggi lebih mengutamakan urusan yang berhubungan dengan uang, kekuasaan dan persaingan. Perbedaan antara Machiavellian tinggi dan rendah bisa dilihat dari motivasi seseorang dalam berperilaku (Jones dan Paulhus, 2009).

\subsubsection{Locus of control}

Locus of control yakni persepsi seseorang yang memiliki keyakinan mereka bertanggung jawab atas takdirnya sendiri (Lubis, 2017: 161). Keyakinan yang dimaksud adalah Keyakinan diri seseorang mampu mengontrol suatu peristiwa kehidupan. Locus of control terdapat dua sisi antara lain internal locus of control dan eksternal locus of control (Schultz dan Schultz, 2013: 433). Internal locus of control merupakan keyakinan dimana hasil yang dicapai berasal dari kemampuan dalam dirinya sementara itu eksternal locus of control merupakan kepercayaan akan hasil yang dicapai berasal dari luar kemampuannya seperti keberuntungan, takdir, dan lain sebagainya. Sumijah (2015) juga berpendapat bahwa saat seseorang diminta untuk mengambil keputusan yang menyebabkan dilema maka mereka akan menghubungkan antara locus of control dan proses penalaran moral yang terjadi.

\subsection{Penelitian Terdahulu}

Penelitian yang dilakukan oleh Uli, Tanjung dan Paulus (2016) ini membahas mengenai pengaruh locus of control, pengalaman audit, dan etika profesional terhadap tindakan auditor saat sedang berada di kondisi konflik audit. Penelitian dilakukan di Pekanbaru yang melibatkan auditor yang bekerja untuk perusahaan akuntan publik sebagai respondennya. Data dianalisis untuk menguji hipotesis menggunakan regresi berganda. Hasil penelitian ini menunjukkan bahwa variabel locus of control, pengalaman audit, dan etika profesional berpengaruh terhadap audit perilaku dalam situasi konflik audit. Persamaan penelitian adalah sama-sama meneliti mengenai locus of control terhadap perilaku dalam situasi konflik audit yang memiliki kesamaan dengan pengambilan keputusan etis yaitu dihadapkan pada dilema etis. Namun perbedaan 


\section{Buana Akuntansi}

YENNY MULIAWATY

Vol. 6 No. 2

ISSN 2528-1119

E-ISSN 2580-5452

penelitian yaitu pada metode penelitian dimana dalam penelitian saat ini, peneliti menggunakan metode eksperimen sedangkan metode menggunakan Uli dkk. (2016) yaitu survey. Selain itu, Uli dkk. (2016) menggunakan KAP yang berlokasi di Pekanbaru, Padang, Palembang, Batam sedangkan penelitian ini menggunakan konsultan pajak sebagai objek penelitiannya.

Penelitian yang dilakukan oleh Yovita dan Rahmawaty (2016) ini membahas mengenai pengaruh gender, ethical sensitivity, locus of control, dan pemahaman kode etik profesi akuntan terhadap perilaku etis. Penelitian dilakukan di Banda Aceh dengan menjadikan mahasiswa akuntansi universitas syiah kuala semester 6 yang sudah mengambil pelajaran auditing sebagai populasi. Datanya dianalisa dengan analisis regresi linier berganda. Hasil penelitian membuktikan bahwa gender, ethical sensitivity, locus of control, dan pemahaman kode etik profesi akuntan terhadap perilaku etis mahasiswa. Persamaan penelitian terletak pada variabel independen yaitu locus of control terhadap perilaku etis dimana memiliki kesamaan dengan pengambilan keputusan etis yaitu sama-sama berada dalam situasi dilema etis. Namun perbedaan penelitian yaitu pada metode penelitian dimana dalam penelitian saat ini, peneliti menggunakan metode eksperimen sedangkan Yovita dan Rahmawaty (2016) menggunakan survey. Selain itu, Yovita dan Rahmawaty (2016) menggunakan mahasiswa di Banda Aceh sedangkan penelitian ini menggunakan konsultan pajak sebagai objek penelitiannya.

Penelitian yang dilakukan oleh Windesi (2017) ini membahas mengenai dampak aspek seseorang yaitu persepsi pentingnya etika dan tanggung jawab sosial, Machiavellianism, dan locus of control terhadap pengambilan keputusan etis akuntan pajak dalam perencanaan pajak. Windesi (2017) menggunakan akuntan pajak perusahaan di Malang sebagai sampel penelitiannya. Data dianalisis untuk menguji hipotesis dengan regresi logistik. Hasil penelitian menjelaskan faktor dari dalam yakni persepsi pentingnya etika dan tanggung jawab sosial, Machiavellianism, dan locus of control berdampak pada pengambilan keputusan etis akuntan pajak perusahaan. Persamaan penelitian terletak pada variabel independen yaitu Machiavellianism, dan locus of control terhadap pengambilan keputusan etis. Namun perbedaan studi ini terletak pada metode penelitian dalam penelitian saat ini, peneliti menggunakan metode eksperimen sedangkan metode yang digunakan Windesi (2017) yaitu survey. Selain itu, Windesi (2017) menggunakan akuntan pajak perusahaan yang berlokasi di malang sedangkan penelitian ini menggunakan IKPI cabang Surabaya sebagai objek penelitiannya.

Penelitian yang dilakukan Tofiq dan Mulyani (2018) ini membahas mengenai pengaruh sifat Machiavellian, pentingnya persepsi etika, dan tanggung jawab sosial (PRESOR), faktor situasional, dan baik internal maupun eksternal locus of control atas pengambilan keputusan etis yang dibuat oleh konsultan pajak yang terdaftar di IKPI Wilayah Banten. Populasi penelitian ini menggunakan konsultan pajak yang IKPI 


\section{Buana Akuntansi}

YENNY MULIAWATY

Vol. 6 No. 2

ISSN 2528-1119

E-ISSN 2580-5452

Wilayah Banten. Data tersebut dianalisis dengan regresi logistik. Hasil penelitian menjelaskan bahwa sifat Machiavellian tidak memiliki pengaruh terhadap pengambilan keputusan etis konsultan pajak, tetapi PRESOR, faktor situasional serta Locus of control Internal dan Eksternal memiliki pengaruh terhadap pajak pengambilan keputusan etis konsultan secara signifikan. Persamaan penelitian terletak pada variabel independen yaitu Machiavellianism, dan locus of control terhadap pengambilan keputusan etis. Namun perbedaan studi ini terletak pada metode penelitian dalam penelitian saat ini, peneliti menggunakan metode eksperimen sedangkan metode yang digunakan Tofiq dan Mulyani (2018) yaitu survey. Selain itu, Tofiq dan Mulyani (2018) menggunakan konsultan pajak IKPI cabang Banten sedangkan penelitian ini menggunakan konsultan pajak IKPI cabang Surabaya sebagai objek penelitiannya.

Penelitian yang dilakukan Dewi dan Dwiyanti (2018) menjelaskan faktor-faktor yang berpengaruh pada perilaku konsultan pajak dalam pengambilan keputusan etis yaitu persepsi etika profesi, Machiavellianism dan preferensi risiko. Populasi penelitian ini menggunakan konsultan pajak IKPI Wilayah Bali. Teknik analisa yang dilakukan yaitu analisis regresi linier berganda. Hasil penelitian membuktikan persepsi etika memiliki pengaruh positif terhadap pengambilan keputusan etis konsultan pajak. Sedangkan Machiavellianism dan preferensi risiko memiliki pengaruh negatif terhadap pengambilan keputusan etis. Persamaan penelitian terletak pada variabel independen yaitu Machiavellianism, dan locus of control terhadap pengambilan keputusan etis. Namun perbedaan studi ini terletak pada metode penelitian dalam penelitian saat ini, peneliti menggunakan metode eksperimen sedangkan metode yang digunakan Dewi dan Dwiyanti (2018) yaitu survey. Selain itu, Dewi dan Dwiyanti (2018) meskipun sama-sama menggunakan konsultan pajak yang terdaftar di IKPI tetapi lokasi cabang yang digunakan berbeda dimana penelitian terdahulu menggunakan cabang Bali sedangkan penelitian saat ini menggunakan Surabaya.

Penelitian yang dilakukan Silitonga dan Hidayat (2019) meneliti pengaruh etika dan tanggung jawab sosial, karakter Machiavellian, dan kompetensi terhadap pengambilan keputusan etis konsultan pajak. Populasi studi ini menggunakan konsultan pajak yang terdaftar di IKPI Wilayah Bandung. Data penelitian di uji dengan menggunakan regresi berganda dengan program SPSS. Berdasarkan hasil pengujian hipotesis diperoleh kesimpulan bahwa etika dan tanggung jawab sosial, karakter Machiavellian, dan kompetensi berpengaruh terhadap pengambilan keputusan etis konsultan pajak. Persamaan penelitian terletak pada variabel independen yaitu Machiavellianism, terhadap pengambilan keputusan etis. Namun perbedaan penelitian ini terletak pada metode penelitian yang digunakan dengan metode eksperimen sedangkan metode yang digunakan Silitonga dan Hidayat (2019) yaitu survey. Selain itu, Silitonga dan Hidayat (2019) menggunakan IKPI cabang Bandung sedangkan penelitian ini menggunakan IKPI cabang Surabaya sebagai objek penelitiannya. 


\section{Buana Akuntansi}

YENNY MULIAWATY

Vol. 6 No. 2

ISSN 2528-1119

E-ISSN 2580-5452

\subsection{Hipotesis}

2.3.1. Pengaruh Sifat Machiavellian terhadap Pengambilan Keputusan Etis Konsultan

Machiavellian merupakan sifat individu seseorang dimana seseorang memiliki kecenderungan secara agresif untuk mempengaruhi serta mengendalikan lingkungan di sekitarnya untuk memenuhi kepentingan pribadinya (Jones dan Paulhus, 2009: 95). Suatu profesi mengharuskan seseorang untuk bersikap profesional dengan memiliki tanggung jawab etis sehingga sifat Machiavellian akan bertentangan dengan kode etik yang telah ditetapkan (Saputri dan Wirama, 2015). Niat serta sifat agresif yang dimiliki seseorang berdasarkan keyakinan akan konsekuensi yang akan diterima juga akan menjadi pertimbangan keputusan apa yang akan diambilnya. Berdasarkan teori planned behavior, sikap akan keyakinan bahwa konsekuensi perilaku tersebut akan memberikan kerugian atau keuntungan juga mempengaruhi proses pengambilan keputusan seseorang. Pada saat seseorang berada dalam dilema etis maka seseorang akan melakukan penalaran moral terlebih dahulu sebelum membuat keputusan.

Selain itu, faktor internal maupun situasional dapat mempengaruhi penalaran

moral dalam pengambilan keputusan (Jones, 1991). Beberapa penelitian mengemukakan bahwa sifat Machiavellian termasuk aspek internal yang dapat mempengaruhi pengambilan keputusan etis. Berdasarkan studi yang dilakukan oleh Silitonga dan Hidayat (2019), semakin tinggi sifat Machiavellian konsultan pajak dapat menyebabkan seseorang cenderung membuat keputusan yang tidak etis dan begitu juga sebaliknya. Pada penelitian yang dilakukan Dewi dan Dwiyanti, (2018) juga mendukung penelitian tersebut dimana sifat Machiavellian yang merupakan faktor individual dari seorang konsultan pajak memiliki pengaruh dalam membuat keputusan etis.

$\mathrm{H}_{1}$ : Semakin tinggi sifat Machiavellian maka konsultan pajak akan cenderung membuat keputusan yang tidak etis.

\subsubsection{Pengaruh Locus of control terhadap Pengambilan Keputusan Etis Konsultan}

Locus of control yakni persepsi seseorang yang memiliki keyakinan mereka bertanggung jawab atas takdirnya sendiri (Lubis, 2017: 161). Keyakinan yang dimaksud adalah Keyakinan diri seseorang mampu mengontrol suatu peristiwa kehidupan. Locus of control terdapat dua sisi antara lain internal locus of control dan eksternal locus of control (Schultz dan Schultz, 2013: 433). Internal locus of control merupakan keyakinan dimana hasil yang dicapai berasal dari kemampuan dalam dirinya sementara itu eksternal locus of control merupakan kepercayaan akan hasil yang dicapai berasal dari luar kemampuannya seperti keberuntungan, takdir, dan lain sebagainya.

Uli, Tanjung dan Paulus (2016) menyatakan bahwa ketika seseorang berada dalam situasi konflik, maka perilaku seorang auditor akan dipengaruhi oleh karakter locus of control-nya. Keyakinan diri seseorang mampu mengontrol suatu peristiwa kehidupan disebut locus of control. Menurut Yovita dan Rahmawaty (2016) menjelaskan bahwa 


\section{Buana Akuntansi}

YENNY MULIAWATY

Vol. 6 No. 2

ISSN 2528-1119

E-ISSN 2580-5452

seseorang dengan locus of control yang baik akan bekerja dengan baik serta berperilaku etis sehingga membawa hasil yang baik pula dan begitu pula sebaliknya. Menurut Mahyarni (2013), theory of planned behavior adalah teori yang memiliki fungsi untuk memperkirakan tindakan seseorang saat seseorang tidak memiliki kontrol atas perilaku nya secara penuh.

Teori planned behavior menjelaskan pada saat individu sedang memperhitungkan perilaku mereka dan keterkaitan dari perilakunya dalam mengambil keputusan maka mereka akan berpikir secara rasional. TPB mengemukakan bahwa sikap akan memberi dampak pada tindakan melewati mekanisme pengambilan keputusan yang cermat serta direncanakan, kemudian seseorang akan melakukan tindakan tertentu saat tindakannya mendapat respon yang baik. Seseorang yakin bahwa orang lain juga mendukung tindakannya serta yakin kalau dia mampu melaksanakannya (Damayanti dkk, 2015). Tiga konstruk TPB seperti sikap, norma subjektif dan persepsi kontrol perilaku seseorang terhadap keyakinan akan konsekuensi, pandangan sekitar serta kesempatan yang ada mempengaruhi keputusan yang akan diambil seseorang. Dalam tingkatan penalaran moral Kohlberg (Santrock, 2007: 119) dijelaskan bahwa individu melakukan penalaran moral dimana bila mereka berbuat baik maka akan mendapat reaksi yang sama. Individu akan melakukan penalaran moral agar dapat membuat keputusan yang rasional dimana individu tersebut sadar akan dampak dan konsekuensi dari keputusan yang diambil sehingga memberikan hasil yang maksimal (Mahyarni, 2013).

Menurut Tofiq dan Mulyani (2018), semakin tinggi locus of control individu dimana individu mempunyai kecenderungan internal locus of control maka keputusan yang akan diambil akan semakin etis. Penelitian ini sejalan dengan penelitian terdahulu yang dilakukan oleh Windesi (2017) yang menjadikan akuntan pajak perusahaan sebagai objek penelitian dimana seseorang dengan kecenderungan internal locus of control akan cenderung berhati-hati serta memikirkan akibat dari keputusan yang akan diambil.

$\mathrm{H}_{2}$ : Semakin tinggi locus of control konsultan pajak dimana kecenderungan internal locus of control, maka keputusan yang diambil akan semakin etis.

\section{Metodologi Penelitian}

Desain eksperimen dalam penelitian ini menggunakan desain faktorial $2 \times 2$ untuk menguji variabel sifat Machiavellian dan locus of control (variabel independen) terhadap pengambilan keputusan etis (variabel dependen). Kemudian peneliti akan mengamati perilaku individu yang telah dimanipulasi dengan membagi partisipan ke dalam empat skenario seperti yang tergambar pada tabel 3.1 berikut ini: 


\section{Buana Akuntansi}

Tabel 3.1. Desain Eksperimen Faktorial 2x2 (sifat Machiavellian dan locus of control)

\begin{tabular}{|c|c|c|c|}
\hline \multicolumn{2}{|c|}{ Perlakuan / Treatment } & \multicolumn{2}{c|}{ Locus of control } \\
\cline { 2 - 4 } sifat & Tinggi & Internal & Eksternal \\
\cline { 2 - 4 } Machiavellian & Rendah & Skenario 1 & Skenario 3 \\
\hline
\end{tabular}

Penggolongan baik sifat Machiavellian maupun locus of control dalam penelitian ini mengacu pada teori yang telah dijelaskan sebelumnya diatas. Dengan demikian, pengujian untuk hipotesis pertama terdiri dari skenario kasus 1-3 dan 2-4 serta pengujian untuk hipotesis kedua terdiri dari skenario kasus 1-2 dan 3-4. Variabel independen sifat Machiavellian dengan kondisi sifat Machiavellian tinggi atau rendah digunakan untuk mengukur hipotesis pertama. Selanjutnya, variabel independen locus of control dengan kondisi internal locus of control atau eksternal locus of control digunakan untuk mengukur hipotesis kedua. Kedua variabel independen akan dimanipulasi dengan memberi kasus pada partisipan. Variabel dependen untuk kedua hipotesis tersebut adalah pengambilan keputusan etis dan partisipan akan diminta untuk mengisi skala dari 0 (kemungkinan kecil) hingga 10 (kemungkinan besar) mengambil keputusan etis dalam kondisi yang telah di treatment.

Teknik pengambilan sampel yang digunakan yaitu nonprobability dengan teknik convenience sampling. Setiap partisipan akan dibagi berdasarkan pengalaman menjadi konsultan pajak agar dapat menekankan sikap Machiavellian setelah itu akan menerima secara acak skenario yang telah dirancang dan partisipan diminta untuk berfikir dan bertindak sesuai dengan skenario yang tergambar dalam instrumen penelitian ini. Partisipan dalam penelitian eksperimen yaitu para konsultan pajak yang merupakan anggota organisasi IKPI cabang Surabaya yang memiliki pengalaman 2-6 tahun dan lebih dari 6 tahun yang akan menjadi obyek penelitian. Konsultan dengan pengalaman 2-6 tahun akan mendapatkan skenario 2 atau 4 secara acak sedangkan jika memiliki pengalaman diatas 6 tahun akan mendapatkan skenario 1 atau 3 secara acak. Teknik analisis data dalam penelitian ini menggunakan Program SPSS versi 23 dengan menguji data, antara lain uji homogenitas dan uji hipotesis yang menggunakan one way anova. 


\section{Buana Akuntansi}

4. Analisis dan Pembahasan

4.1. Test Homogenity of Variance

Tabel 4.1. Levene's Test for Equity of Variances (Sifat Machiavellian)

Dependent Variable: Pengambilan Keputusan Etis

\begin{tabular}{|c|c|c|c|}
\hline F & df1 & df2 & Sig. \\
\hline 0,152 & 1 & 143 & 0,698 \\
\hline
\end{tabular}

Sumber: Data primer diolah (2021)

Hasil pengujian levene's test untuk variabel independen sifat Machiavellian diatas menunjukkan hasil nilai $\mathrm{F}$ sebesar 0,152 dan signifikansi sebesar 0,698 dan dapat diambil kesimpulan bahwa sifat Machiavellian memiliki varians sama atau homogen sehingga dapat diterima.

Tabel 4.2. Levene's Test for Equity of Variances (Locus of Control) Dependent Variable: Pengambilan Keputusan Etis

\begin{tabular}{|c|c|c|c|}
\hline F & df1 & df2 & Sig. \\
\hline 0,156 & 1 & 143 & 0,693 \\
\hline
\end{tabular}

Sumber: Data primer diolah (2021)

Hasil pengujian levene's test untuk variabel independen locus of control diatas menjelaskan hasil nilai $F$ sebesar 0,156 dan signifikansi sebesar 0,693 dan dapat diambil kesimpulan bahwa locus of control memiliki varians sama atau homogen sehingga dapat diterima. 


\section{Buana Akuntansi}

YENNY MULIAWATY

Vol. 6 No. 2

ISSN 2528-1119

E-ISSN 2580-5452

\subsection{Pengujian Hipotesis}

Hasil pengolahan data untuk hipotesis pertama melalui pengujian ANOVA dapat dilihat pada tabel berikut:

Tabel 4.3. Tests of Between-Subjects Effects (Sifat Machiavellian)

Dependent Variable: Pengambilan Keputusan Etis

\begin{tabular}{|l|r|r|r|r|r|}
\hline Source & $\begin{array}{r}\text { Type III } \\
\text { Sum of } \\
\text { Squares }\end{array}$ & Df & $\begin{array}{c}\text { Mean } \\
\text { Square }\end{array}$ & \multicolumn{1}{|c|}{ F } & Sig. \\
\hline $\begin{array}{c}\text { Corrected } \\
\text { Model }\end{array}$ & $945,944^{\mathrm{a}}$ & 1 & 945,944 & 561,717 & 0,000 \\
$\quad$ Intercept & 4608,178 & 1 & 4608,17 & 2736,413 & 0,000 \\
SM & 945,944 & 1 & 945,944 & 561,717 & 0,000 \\
Error & 240,815 & 143 & 1,684 & & \\
Total & 5824,000 & 145 & & & \\
$\quad$ Corrected & 1186,759 & 144 & & & \\
Total & & & & \\
\hline
\end{tabular}

a. $\mathrm{R}$ Squared $=0,797$ (Adjusted R Squared $=0,796$ )

Dari tabel 4.3, dapat dilihat bahwa nilai $\mathrm{F}$ untuk variabel independen sifat Machiavellian adalah sebesar 561,717 dan memiliki nilai signifikansi sebesar 0,000 sehingga dari hasil pengolahan data ini dapat dilihat sifat Machiavellian tinggi memiliki perbedaan dengan sifat Machiavellian rendah terhadap pengambilan keputusan etis konsultan pajak. Maka membuktikan hipotesis pertama, berikut adalah tabel means untuk variabel sifat Machiavellian:

Tabel 4.4. Rata-Rata Sifat Machiavellian

Dependent Variable: Pengambilan Keputusan Etis

\begin{tabular}{|c|c|c|c|}
\hline Sifat Machiavellian & Mean & $\begin{array}{c}\text { Std. } \\
\text { Deviation }\end{array}$ & $\mathrm{N}$ \\
\hline Machiavellian_Tingg & 8,1918 & 1,27647 & 73 \\
\hline Machiavellian_Rend & 3,0833 & 1,31888 & 72 \\
\hline Total & 5,6552 & 2,87078 & 145 \\
\hline
\end{tabular}

Sumber: Data primer diolah (2021)

Pada hasil rata-rata diatas, sifat Machiavellian tinggi memiliki rata-rata sebesar 8,1918 dan sifat Machiavellian rendah memiliki rata-rata sebesar 3,0833. Terdapat selisih antara rata-rata keduanya dengan sifat Machiavellian tinggi yang memiliki means lebih besar yaitu 8,1918. Berdasarkan penjelasan diatas, maka dapat diambil kesimpulan 


\section{Buana Akuntansi}

YENNY MULIAWATY

Vol. 6 No. 2

ISSN 2528-1119

E-ISSN 2580-5452

hipotesis pertama diterima dimana konsultan pajak dengan sifat Machiavellian tinggi akan lebih cenderung mengambil keputusan tidak etis dibandingkan konsultan pajak dengan sifat Machiavellian rendah.

Pengolahan data selanjutnya dilakukan untuk menguji hipotesis kedua, berikut hasil yang dapat dilihat pada tabel dibawah ini:

Tabel 4.5. Tests of Between-Subjects Effects (Locus of Control)

Dependent Variable: Pengambilan Keputusan Etis

\begin{tabular}{|c|r|r|r|r|r|}
\hline Source & \multicolumn{1}{|c|}{$\begin{array}{c}\text { Type III } \\
\text { Sum of } \\
\text { Squares }\end{array}$} & Df & $\begin{array}{c}\text { Mean } \\
\text { Square }\end{array}$ & \multicolumn{1}{c|}{ F } & Sig. \\
\hline $\begin{array}{c}\text { Corrected } \\
\text { Model }\end{array}$ & $47,491^{\mathrm{a}}$ & 1 & 47,491 & 5,961 &, 016 \\
Intercept & 4654,691 & 1 & 4654,69 & 584,253 &, 000 \\
LC & 47,491 & 1 & 47,491 & 5,961 &, 016 \\
Error & 1139,267 & 143 & 7,967 & & \\
Total & 5824,000 & 145 & & & \\
$\quad$ Corrected & 1186,759 & 144 & & & \\
Total & & & & \\
\hline
\end{tabular}

a. R Squared $=, 040$ (Adjusted R Squared $=, 033$ )

Pada tabel 4.5 yang tercantum diatas, dapat dilihat nilai $\mathrm{F}$ untuk variabel independen Locus of Control adalah sebesar 5,961 serta mempunyai nilai signifikansi sebesar 0,016 sehingga dari hasil pengolahan data ini dapat dilihat internal locus of control mempunyai perbedaan dengan eksternal locus of control terhadap pengambilan keputusan etis konsultan pajak. Untuk membuktikan hipotesis pertama, berikut adalah tabel means untuk variabel Locus of Control:

Tabel 4.6. Rata-Rata Locus of Control

Dependent Variable: Pengambilan Keputusan Etis

\begin{tabular}{|ll|r|r|r|}
\hline \multicolumn{2}{|c|}{ Locus Of Control } & Mean & $\begin{array}{c}\text { Std. } \\
\text { Deviation }\end{array}$ & $\mathrm{N}$ \\
\hline \multirow{2}{*}{$\begin{array}{l}\text { Locus_of_Control_Interna } \\
\end{array}$} & Locus_of_Control_Ekstern & 6,2394 & 2,83077 & 71 \\
al & & 5,0946 & 2,81468 & 74 \\
& Total & 5,6552 & 2,87078 & 145 \\
\hline
\end{tabular}

Sumber: Data primer diolah (2021) 


\section{Buana Akuntansi}

YENNY MULIAWATY

Vol. 6 No. 2

ISSN 2528-1119

E-ISSN 2580-5452

Pada hasil rata-rata diatas, internal locus of control memiliki rata-rata sebesar 6,2394 dan eksternal locus of control memiliki rata-rata sebesar 5,0946. Terdapat selisih antara rata-rata keduanya dengan internal locus of control yang memiliki means lebih besar yaitu 6,2394. Berdasarkan penjelasan diatas, maka dapat diambil kesimpulan hipotesis kedua diterima dimana konsultan pajak dengan locus of control tinggi yang memiliki kecenderungan internal locus of control akan lebih cenderung mengambil keputusan etis dibandingkan konsultan pajak dengan locus of control rendah yang memiliki kecenderungan eksternal locus of control.

\subsection{Pembahasan}

Hasil dari penelitian ini sejalan dengan teori penalaran moral mengemukakan bahwa pada saat seseorang berada dalam dilema etis maka seseorang akan melakukan penalaran moral sebelum membuat keputusan. Konsultan pajak yang memiliki kecenderungan eksternal locus of control membuat keputusan tidak etis apabila dijelaskan dengan TPB yaitu adanya niat ketika mengetahui bahwa konsekuensi yang didapatkan menguntungkannya. Kemudian hal ini didukung dengan adanya tekanan dari klien yang menjadi alasan bahwa keputusan tidak etis tersebut merupakan pengaruh faktor dari luar sehingga tidak dapat mengontrol perilakunya. Hal ini menyebabkan keputusan yang dibuat konsultan pajak menjadi tidak etis. Hal ini membuat konsultan pajak dapat memenangkan kasus yang mereka hadapi dengan pihak DJP seperti pemeriksaan, restitusi, banding dengan cara apapun. Hal ini membuat konsultan pajak akan melakukan berbagai cara dengan memanfaatkan celah peraturan perpajakan meskipun hal tersebut melanggar etika profesi mereka

Theory of planned behavior menjelaskan bahwa ada tiga konstruk yang melatarbelakangi seseorang saat merencanakan perilakunya yaitu niat serta sifat agresif yang dimiliki, norma subjektif yang didukung dengan faktor eksternal yaitu adanya tekanan klien dan keyakinan bahwa orang lain juga mendukung tindakannya (Damayanti dkk, 2015). Hal ini menyebabkan keputusan yang dibuat konsultan pajak menjadi tidak etis. Teori penalaran moral mengemukakan bahwa pada saat seseorang berada dalam dilema etis maka seseorang akan melakukan penalaran moral sebelum membuat keputusan.

Penelitian ini juga sejalan dengan hasil yang dilakukan oleh Silitonga dan Hidayat (2019) dimana semakin tinggi sifat Machiavellian konsultan pajak maka seseorang lebih condong membuat keputusan yang tidak etis dan begitu juga sebaliknya. Purnamasari dan Chrismastuti (2006) mengatakan individu yang mempunyai sifat Machiavellian yang tinggi lebih suka melakukan manipulatif dan juga melakukan penipuan serta mereka akan melakukan segala cara demi keuntungan pribadinya. Mereka kurang memiliki moral yang baik sehingga dapat menyebabkan perilaku tidak etis karena mereka tidak akan segan untuk melanggar aturan dalam kode etik profesi mereka demi mencapai tujuan pribadinya (Saputri dan Wirama, 2015). 


\section{Buana Akuntansi}

YENNY MULIAWATY

Vol. 6 No. 2

ISSN 2528-1119

E-ISSN 2580-5452

Sifat Machiavellian pasti dimiliki oleh setiap individu tetapi dengan tingkatan yang berbeda-beda karena memang setiap individu menyadari bahwa ia memiliki sifat manipulatif. Setiap individu dengan sifat Machiavellian tinggi ataupun rendah dapat mengambil keputusan tidak etis. Hal ini bergantung pada penalaran moral yang dilakukan setiap orang sebelum mengambil keputusan. Konsekuensi dari perilaku yang akan dilakukan memberikan keuntungan juga mempengaruhi seseorang ketika mengambil keputusan. Akan tetapi, seseorang yang memiliki sifat Machiavellian tinggi akan cenderung mengambil keputusan tidak etis dibandingkan seseorang dengan sifat Machiavellian rendah.

Hipotesis kedua penelitian eksperimen ini diterima dimana konsultan pajak dengan locus of control tinggi yang memiliki kecenderungan internal locus of control akan lebih cenderung mengambil keputusan etis dibandingkan konsultan pajak dengan locus of control rendah yang memiliki kecenderungan eksternal locus of control. Variabel independen locus of control termasuk aspek yang memiliki pengaruh pada seseorang dalam mengambil keputusan etis. Menurut theory of planned behavior, individu yang memiliki kecenderungan eksternal locus of control memiliki keyakinan bahwa perilaku yang dilakukan dan kejadian yang terjadi merupakan pengaruh dari faktor eksternal. Hasil dari penelitian ini didukung dengan penelitian yang dilakukan oleh Tofiq dan Mulyani (2018), semakin tinggi locus of control individu dimana individu mempunyai kecenderungan internal locus of control maka keputusan yang akan diambil akan semakin etis. Penelitian ini sejalan dengan penelitian terdahulu yang dilakukan oleh Windesi (2017) yang menjadikan akuntan pajak perusahaan sebagai objek penelitian dimana seseorang dengan kecenderungan internal locus of control akan cenderung berhati-hati serta memikirkan akibat dari keputusan yang akan diambil.

Setiap individu memiliki locus of control hanya saja ada yang cenderung internal locus of control, ada pula yang lebih cenderung eksternal locus of control. Individu yang cenderung memiliki internal locus of control ataupun eksternal locus of control dapat mengambil keputusan etis. Hal ini bergantung pada sikap dan keyakinan terhadap konsekuensi atas perilaku yang akan dilakukan setiap orang sebelum mengambil keputusan. Keyakinan akan perilaku yang akan dilakukan memberikan keuntungan juga mempengaruhi seseorang ketika mengambil keputusan. Akan tetapi, seseorang dengan locus of control tinggi yang mempunyai kecenderungan internal locus of control akan lebih cenderung mengambil keputusan etis dibandingkan seseorang dengan locus of control rendah yang lebih condong eksternal locus of control.

\section{Kesimpulan, Keterbatasan, dan Saran}

\subsection{Kesimpulan}

Berdasarkan hasil pengujian yang telah dilakukan dalam penelitian ini, maka simpulan yang dapat diperoleh yaitu semakin tinggi sifat Machiavellian yang dimiliki konsultan pajak maka keputusan yang akan diambil semakin tidak etis. Begitu juga sebaliknya apabila semakin rendah sifat Machiavellian yang dimiliki konsultan pajak 


\section{Buana Akuntansi}

YENNY MULIAWATY

Vol. 6 No. 2

ISSN 2528-1119

E-ISSN 2580-5452

maka keputusan yang akan diambil semakin etis. Hal ini disebabkan konsultan pajak memiliki kepentingan pribadi yang mengharapkan imbalan ekonomis dari klien sehingga konsultan pajak cenderung membuat keputusan etis dengan memenuhi permintaan klien dan mengabaikan etika yang berlaku. Seseorang dengan locus of control tinggi yang memiliki kecenderungan internal locus of control akan lebih cenderung mengambil keputusan etis dibandingkan seseorang dengan locus of control rendah yang memiliki kecenderungan eksternal locus of control. Hal ini disebabkan seseorang dengan kecenderungan internal locus of control akan lebih berhati-hati serta memikirkan akibat dari keputusan yang akan diambil.

\subsection{Keterbatasan}

Keterbatasan dalam penelitian ini hanya menggunakan anggota IKPI cabang Surabaya. Di Indonesia sendiri sudah terdapat 4 asosiasi konsultan pajak yang diakui oleh Negara. Setiap asosiasi pasti memiliki kode etik sendiri dan program pengembangan untuk menunjang profesionalitas anggota nya. Oleh sebab itu, hasil dari penelitian ini bisa dikatakan belum dapat mewakili seluruh konsultan pajak yang ada di Indonesia.

\subsection{Saran}

Adapun saran yang diberikan dari penelitian ini yaitu para konsultan pajak harus lebih memahami dan memperhatikan kode etik yang dimiliki setiap asosiasi. Konsultan pajak juga perlu lebih berhati-hati dalam membuat keputusan karena konsultan pajak juga merupakan jembatan yang menjadi perwakilan pihak Direktorat Jenderal Pajak untuk membantu dalam mengedukasi para wajib pajak di Indonesia. Selain itu, bagi asosiasi konsultan pajak yang dalam hal ini yaitu IKPI sebaiknya lebih memperbanyak program penyadaran dan pengembangan dalam bidang etika profesi agar anggota IKPI memiliki integritas dalam menjalankan profesinya. Sedangkan bagi Direktorat Jenderal Pajak diharapkan bekerja sama dengan asosiasi-asosiasi konsultan pajak dengan menerapkan pakta integritas yang menjunjung tinggi integritas baik Direktorat Jenderal Pajak maupun konsultan pajak yang tergabung dalam asosiasi konsultan pajak.

\section{Daftar Pustaka}

Ajzen, I. (1991). The Theory of Planned Behavior. Organizational Behavior and Human Decision Process, 50: 179-211.

Anjelina, Y. (2019). Faktor-Faktor Yang Mempengaruhi Sensitivitas Etis. Jurnal Akuntansi Bisnis, Vol. 17, Nomor 1, 45-53.

Blanthorne, C., H. A. Burton dan Fisher, D. (2013). The Aggressiveness of Tax Professional Reporting: Examining the Influence of Moral Reasoning. Advances in Accounting Behavioral Research, 16, 149 - 181.

Damayanti, T. W., Sutrisno, Subekti, I., dan Baridwan, Z. (2015). Trust and Uncertainty Orientation: An Efforts to Create Tax Compliance in Social Psychology Framework. Procedia-Social and Behavioral Sciences, Vol. 211: 938-944. 


\section{Buana Akuntansi}

YENNY MULIAWATY

Vol. 6 No. 2

ISSN 2528-1119

E-ISSN 2580-5452

Dewi, N. M. A. D. L., dan Dwiyanti, K. T. (2018). Faktor dalam Pengambilan Keputusan Etis oleh Konsultan Pajak: Individual dan Situasional. Jurnal Ilmiah Akuntansi Dan Bisnis, Vol. 3, Nomor 1, 23-25.

Doyle, E., Hughes. J. F., dan Summers. B. (2013). An Empirical Analysis of the Ethical Reasoning of Tax Practitioners. Journal of Business Ethics, Vol. 114, Nomor 2, 325-339.

Fahmi, I. (2017). Etika Bisnis: Teori, Kasus, dan Solusi. Bandung: Alfabeta.

Jiang, H., dan Bowen, S. A. (2011). Ethical Decision Making in Issues Management Within Activist Groups. Public Relations Journal, Vol. 5, Nomor 1, 1-21.

Jones, D. N., dan Paulhus, D. L. (2009). Machiavellianism. In M. R. Leary \& R. H. Hoyle (Eds.), Handbook of individual differences in social behavior (P. 93-108).

Jones, T. M. (1991). Ethical Decision Making by Individuals in Organizations: An IssueContingent Model. Academy of Management Review, Vol. 16, Nomor 2, 366-395.

Lubis, A. I. (2017). Akuntansi Keperilakuan: Akuntansi Multiparadigma. Jakarta, Salemba Empat.

Mahyarni. (2013). Theory of Reasoned Action Dan Theory of Planned Behavior (Sebuah Kajian Historis Tentang Perilaku). Jurnal El-Riyasah, Vol. 4, Nomor 1, 13-23

Nikara, I.A.G.I.K., dan Mimba, N.I.S.H. (2019). Pengaruh Love of Money, Machiavellian, Idealisme Dan Religiusitas Pada Persepsi Etis Mahasiswa Akuntansi. E-Jurnal Akuntansi Universitas Udayana, Vol. 26: 536-562.

Pitaloka, F. D., dan Ardini, L. (2017). Analisis Faktor-Faktor Individual Dalam Pengambilan Keputusan Etis Oleh Konsultan Pajak. Jurnal Ilmu dan Riset Akuntansi, Vol. 6, Nomor 8, 123.

Purnamasari, St.V., dan Chrismastuti, A.A. (2006). Dampak Reinformcement Contingency Terhadap Hubungan Sifat Machiavellian Dan Perkembangan Moral. Simposium Nasional Akuntansi 9, Padang.

Rahardjo, S. S. (2018). Etika Dalam Bisnis \& Profesi Akuntan dan Tata Kelola Perusahaan. Jakarta: Salemba Empat.

Santrock, J. W. (2007). Perkembangan Anak Edisi Ke-11 Jilid 2. Jakarta: Erlangga.

Saputri, I.G.A.Y., dan Wirama, D.G. (2015). Pengaruh Sifat Machiavellian Dan Tipe Kepribadian Pada Perilaku Disfungsional Auditor. E-Jurnal Ekonomi dan Bisnis Universitas Udayana, Vol. 4.02, 70-86.

Schultz, D.P., dan Schultz, S.E. (2013). Teori Kepribadian Edisi 10. Terjemahan oleh Paulina Diana, 2014, Jakarta: Buku Kedokteran EGC.

Silitonga, S. E., \& Hidayat, N. (2019). The Effect Of Ethics \& Social Responsibility, Machiavellian Character, and Competency On Ethical Decision Making Of Tax Consultant (Case Study Of Tax Consultant In Bandung). South East Asia journal of Contemporary Business, Economics and Law, Vol. 20, Nomor 5, 1-8.

Sumijah. (2015). Locus Of Control pada Masa Dewasa. Procedia: Seminar Psikologi Dan Kemanusiaan, Malang.

Suzila. (2018). Pengaruh Locus of Control Dan Lingkungan Etika Terhadap Niat Melakukan Whistleblowing (Studi Eksperimentasi Pada SKPD di Lubuk Sikaping, Kabupaten Pasaman). Jurnal Akuntansi, Vol 6, Nomor 3, 1-11.

Tofiq, T. A., dan Mulyani, S. D. (2018). Analisis Pengaruh Locus of Control, Etika Dan Tanggung Jawab Sosial, Faktor Situasional Dan Locus Of Control Terhadap Pengambilan Keputusan 


\section{Buana Akuntansi}

YENNY MULIAWATY

Vol. 6 No. 2

ISSN 2528-1119

E-ISSN 2580-5452

Etis Oleh Konsultan Pajak. Scientific Journal Of Refelction: Economic, Accounting, Management and Business, Vol. 1, Nomor 4, 91-100.

Uli, A., Tanjung, A., dan Paulus, S. (2016). Pengaruh Locus of Control, Pengalaman Auditor, Dan Etika Profesional Terhadap Perilaku Auditor Dalam Situasi Konflik Audit. Jurnal Online Mahasiswa Fakultas Ekonomi Universitas Riau, Vol. 3, Nomor 1, 190-203.

Windesi, E. M. (2017). Pengaruh Faktor Individu: Persepsi Pentingnya Etika dan Tanggung Jawab Sosial, Machiavellianism, dan Locus of Control Terhadap Pengambilan Keputusan Etis Akuntan Pajak Dalam Perencanaan Pajak (Tax Planning). Jurnal Ilmiah FEB Universitas Brawijaya, Vol. 5, Nomor 1, 1-19.

Yovita, C. S. D., dan Rahmawaty. (2016). Pengaruh Gender, Ethical Sensitivity, Locus of Control, dan Pemahaman Kode Etik Profesi Akuntan Terhadap Perilaku Etis Mahasiswa Akuntansi Universitas Syiah Kuala. Jurnal Ilmiah Mahasiswa Ekonomi Akuntansi, Vol. 1, Nomor 2, 252-263. 